\title{
Review Paper On Competencies Essential For Project Manager
}

\author{
DR. GAYATRI KULKARNI,
}

Indira Institute Of Management, Pune, Maharashtra, India

\begin{abstract}
Competency is a term widely used in the IT industry. Competency is defined as " an underlying characteristic of a person which results in effective and /or superior performance in a job" (Boyatzis R. , 1982)In order to be successful in a business market, project-based organizations should be successful in theirprojects.(Ghasem Omidvar F. J., 2011). One of the factors that influence project success is the employment of competent project managers. (Ghasem Omidvar, 2011).Crawford (2000) also reiterates the point that a competent project manager is a factor that affects project success. The objective of this paper is to identify competencies essential for Project Manager which lead to the successful project. The competencies are majorly divided into technical competencies and behavioural competencies. This paper attempts to review the literature available and propose the competencies important for a Project Manager.
\end{abstract}

Keywords:

Project Manager, Technical Competency , Behavioural Competency

Article Received: 18 October 2020, Revised: 3 November 2020, Accepted: 24 December 2020

\section{INTRODUCTION:}

The history of competency can be traced back to January 1973, where McClelland for the first time introduced the concept of competency testing. In order to be successful in a business market, project-based organizations should be successful in their projects. One of the factors that influence project success is the employment of competent project managers. (Ghasem Omidvar, 2011).Crawford (2000) points out that a competent project manager is a factor that affects project success. Hence it is essential to understand the competencies of project manager leading to successful projects

\section{RESEARCH METHODOLOGY AND OBJECTIVES:}

The study is based on secondary data.Data has been collected from data published in various research papers, reports and journals.

Objectives of research:

1) To understand the concept the competency

2) To recognise the various types of competencies vital for Project Managers for successful project implementation.

\section{DISCUSSION:}

David McClelland (1973) for the first time offered competencies as critical differentiator of performance. He insisted on criterion testing as a test for competence, where testers would understand the job and analyse the performance into various components which constitute superior performance. (McClelland, 1973 January) .He defined competence as " a personal trait or set of habits that leads to more effective or superior job performance"

"Competence is an individual's ability to use and connect acquired knowledge and experience in complex, varied, and unpredictable situations". (Perrenoud.P, 1997)"Maximum performance is believed to occur when the person's capability or talent is consistent with the needs of the job demands and the organizational environment"(Boyatzis,2008; (Boyatzis, 1982))

Lee (1995) reported that business functional knowledge and interpersonal /management skills were considered the most important skills for an IS professional while technical skills were viewed as the least important. Richards (1998), based on a survey of 47 IS managers, found that "the most highly regarded skills by the sample group were 
those associated with business or interpersonal skills, while technical skills received the lowest ratings" (Matthew E. Swinarski, 2009)

Crawford (1997) defined "competency according to three dimensions, which are project management knowledge, project management performance and personal competencies. Thus, a competent project manager should fulfil all three dimensions requirements".

GhasemOmidvar et.al. (1997) defined competency as "competency as performance standard, which is expected to achieve". This competency is also known as functional competency (Martin and Staines, 1994) or task-specific competency (Bergenhengouwen, 1996) or job-focused (Holmes and Joyee, 1993). Elkin (1990) addressed this competency as "micro competency".

Crawford (2000) points out that "a competent project manager is a factor that affects project success".

Lyn Crawford discusses about the changing aspects of Project management from hard to soft industries and the diversifying role of project managers from individual contributors to the team based one and the complexity and multicipility of projects at hand. She also concludes that organizational factors beyond the control of individual project manager need to be considered and the project manager role need to be defined and aligned to the definition of the standards specified. (Crawford, 2000)

(Micheal Birkhead M. S., 2000) studied core competencies and training essential for project managers in South Africain engineering, IT and construction sector. The order of importance of competency was found be planning and controlling, personal influence which includes honesty and integrity, goal focus, problem solving, team leadership, project team development and project context. Awareness of legislation was considered as important competency for construction and engineering while team building emerged as important competency for IT.
Forlarge scale projects in Engineering, four competencies were found out viz. entrepreneurial (comprising of marketing and project opportunity), technical (basic knowhow), evaluative (evaluate cost and risk measurement) and relational (skill and knowhow for developing projects) (Lampel, 2001)

Indian Managers take the ethical puzzle stance less frequently, when responding to ethical issues at work as compared to UK Managers. They also experience tension between their own ethical beliefs and work ethics or work beliefs and would look for procedural justice while deciding to make the staff jobless. (Sanghi, 2002)

It was observed by Agrawal that due to shortage of Project Managers, many organizations promote employees at their early career stage, when they are still not equipped with managerial skills and gaining technical experience (Narendra M. Agrawal, 2003). The paper pointed out the reluctance of employees to make transition from technical to managerial positions.

In a research carried out by Crawford (2005), "results showed that competencies valued by project management practitioners were different from competencies valued by senior management".

Competence is the ability to use knowledge and/or skills as well as personal characteristics, at work (IPMA Competence Baseline version3.0, 2006); it is an individual's ability to mobilize and combine knowledge, skills, and attitudes in order to implement an activity in a situation, in a specific context. (Guido Capaldo, 2006)

According to Boyatzis, 3 threshold abilities and 3 outstanding competencies were required for outstanding performance (Boyatzis, 2008). The three threshold clusters include experience, knowledge and reasoning ability while outstanding competencies include cognitive competencies, emotional intelligence and social intelligence.

According to a study by F. Delamare Le Deist \& J. Winterton, it was observed that multidimensional approaches towards competency were 
emerging. USA approach predominantly was behaviour oriented to which the functional and cognitive component was added while the UK approach included behaviour competencies to occupational functional competencies. Though France, Austria and Germany have adopted competence approach late, they developed a holistic framework consisting of social, cognitive, functional and domain or subject competence (WINTERTON, March 2005)

(Muller, 2005)opined a different that observation that project managers leadership style and competency have no impact on project success and cannot be considered as critical success factor due to the novel, unique and transient nature of projects. (Muller, 2005)

"In case of innovative projects, integration of people from business functions in cross-functional teams do not lead to significantly higher project success but instead co-location of people does" (Hans Georg Gemu“nden, 2005). Thus, structural and resource autonomy do not add to project success (Hans Georg Gemu“nden, 2005)

Amongst the study of competencies for consulting Project manages in Malaysia, 199 competence variables were identified grouped in to 4 competences. i.e. cognitive competence, ethical competence, personal or behavioural competence and functional competence. The order is cognitive competence, ethical competence, personal or behavioural competence and lastly followed by functional competence. (Dr. Abdullah Mahmood, 2006)

A competent individual is one with the suitable personal characteristics, knowledge, skills, and abilitiesneeded to work well or successfully achieve planned goals. (Sanghi, 2007)

Helgadottir (2007) identified "that project manager's thinking competencies have three dimensions viz. creative thinking, logical thinking and the ethical thinking". Ethical behaviour helps to build ethical environment for decision making, prompt members of organization to behave according to the norms and also job satisfaction of stakeholders. Employees behaviour and decision making are influenced by their manager's behaviour.

In 2008, Boyatzis adopted the term competency as "an underlying characteristic of an individual that is causally (change in one variable cause change in another) related to superior performance in a job."Mary Jones studied various ways implemented by ERP Project managers in energy sector to overcome team obstacles. The obstacles to the team were internal and external. External obstacles arise from various perceptions, references and previous experiences of team members while internal obstacles emerge as the team progresses and team member differences. The obstacles can be overcome by structural changes in the team or bringing teams interventions. These interventions have to be considered along with leadership, control and coordination which are essential for project success. The paper suggests the importance of team building(C.Jones, 2008)

While trying to understand the differences and similarities in leadership and management, in British Royal Navy, (Dulewicz,2008) pointed out that the general finding that conceptual skills are important more at senior level while technical skills are important at junior level (Dulewicz M. Y., 2008).

Listening skills and verbal communication was rated as one of the top 10 competencies for project managers ((Linda Henderson; 2008, Krahn \& Hartment; 2006)). Linda during her study of project managers in USA have found out that decoding competency of project managers positively impacts the team members satisfaction and project managers encoding competency impacts the productivity of team members (Henderson, 2008)

As per the study done with UK Project Managers; Project manager's leadership competency directly contributes to the success of project. The researchers divided the leadership competencies into emotional and social competency, intellectual competency and managerial competency. Among 
the leadership competencies, management related leadership competencies i.e. managing resources, empowering employees and developing people play a significant role in project success. (Dulewicz L. G., December 2008)

The study done in large scale construction sector in Ghana by Divine KwakuAhadzie, David Gavin Proverbs \& Paul Olomolaiye elaborates the point that task-contextual approach contributes to performance of Construction Project Managers where the task behaviours (job specific behaviours)contributes more than the contextual behaviours (non job specific but contribute informally to organization's effectiveness.(Divine Kwaku Ahadzie, 2008)

"Because the competencies are derived from performance inductively, they reflected effective job performance. Since they were identified and articulated in terms of the actions and intent, they are a behavioural approach to a person's talent". (Richard.E.Boyatzis, 2008). In 1982, Boyatzis had alleged that "maximum performance is believed to occur when the person's capability or talent is consistent with the needs of the job demands and the organizational environment".

Gregory J. Skulmoski, \& Francis T. Hartman explored the leadership competencies essential for IT project managers in USA during various phases of project to be successful. Objectivity is essential during Initiation phase, while ownership, decisiveness and motivations are important during planning and implementation phase and credit giving ability is found useful during closeout. (Hartman, 2009)

The various IT competence include IT application knowledge, initiative, adaptability, cooperation, communication skill, regulation shape, thought, innovation and attitude. A study in China concluded that knowledge can be improved by training and stresses on the fact that in-depth study of competence is essential. (Wong, October 2010) (Gregory J. Skulmoski, 2010)studied the "soft competencies by project phase that Information Systems (IS) project managers require for project success through project managers and business leaders located in Calgary, Alberta and Canada". Amongst those; communication competencies, listening skills and generating feedback or questioning was required more in initiation and planning phase followed by implementation and closeout. Writing skills are required most in closeout phase. Amongst leadership competency, articulation of business problem, political awareness is most required in initiation and planning phase followed by implementation and closeout. Sharing of information is required highest during closeout phase. Among the personal attribute, creativity was considered most important during planning phase, eye for detail in planning and implementation phase and selfevaluation during close out phase. Among the professional competencies; Theoretical knowledge is most required during planning phase. Result orientation is seen important during implementation stage Quality and ethical conducts were seen important in closeout phase. Among the Project management competency, Team building were considered important during initiation phase, Project Management were considered important during planning and implementation stage followed by managing expectation, which was considered most important during closeout stage.

Clarke considered the relationship of Emotional Intelligence (EI) and transformational relationship amongst Project managers in UK (Clarke, 2010) wherein EI ability and empathy were related to team workand conflict management $\mathrm{He}$ also found out significant relationship between empathy and attentiveness of Project manager which is essential for positive attitude and building teamwork essential for project success and effective leadership behaviour.

"Traditionally project management is understood as using the right tools and techniques for being successful, regardless of a project manager's match of personality with project type"(Ralf Muller,2010PMI, 2004)) Leadership ability of project managers like influencing and motivating the team are important for project success.(Ralf Muller, 2010) 
A similar study done in Construction sector in Taiwan by Li-RenYanga, Chung-FahHuangb, Kun-Shan Wua discussed about relationship between various leadership styles of project manager, project type and performance. Project performance, team work and leadership style (Transactional and transformation leadership style)of project manager were found to be highly correlated (Li-Ren Yanga, 2011)

In a study, both the IT Recruiters and IT executives agreed that PMP certified does not lead to higher success rate of projects (Jo Ann Starkweather, 2011) Instead their emphasis on soft skills such as the ability to communicate at multiple levels, and the tacit knowledge of knowing when to exercise leadership and how to do this effectively are critical to eventual project success.

Project Management Practices differ in India not only on the basis of size and project complexity but also on but also across sectors and forms of ownership i.e public or private. However, in Infrastructure projects the time and cost overruns are see often which can be attributed to poor project management practices (FICCI, 2011)

Though mastery over Project management practices is important for project managers, PMP certification is one of the least valued parameters as compared to other competencies. (Stevenson, 2011). The competencies regarded important were leadership, communication, verbal and written skills attitude and ability to deal with ambiguity, work history, experience, ability to escalate cultural fit, technical expertise, education, length of prior engagement, past team size and the last being PMP certification.

Project managers in Indian IT \& ITeS face a skill gap in Planning skill, cost management, client interaction, risk management and time management (PMI, 2012)Similar observations were given in the report by KPMG \& CII that project time and cost overruns were attributed to non-deployment of project management practices. (CII, 2012)
A study was carried out in Czech Republic to understand which areas should the faculty offering Project Management certificate should focus so as to gain maximum learning from the courses wherein the technical competency, project requirement and objective was found to be having highest impact. Technical competencies were found of higher importance while behavior and contextual competencies were relatively of same importance. (Jan Bartoška, October 2012)

(Panagiotis Trivellas, 2013 )studied the relationship between behavioural and managerial competencies and the project success for Greek Project Managers .Among the behavioural competencies, Project Managers in successful projects considered ethical values, openness and reliability as the most dominant ones, while relaxation, creativity and results orientation were found less important. Considering managerial competencies, promoting continuous improvement, interpersonal relationships and teamwork were ranked higher as compared to managing competitiveness, energizing employees and controlling the system .Successful Project managers exhibited high level of self-awareness amongst emotional competency.

Pandya studied the leadership competencies essential for Project leaders in India through semi structured interview, where participants emphasized the role of project manager as a bridge between stakeholders, ground worker, staff, management, and project sponsors. They focused more on behavioural competencies than technical competencies ; technical ones being the prerequisite (Pandya, 2014).The research was carried from individuals in Banking and Finance, Engineering, IT and research advisory firms.

Competency is the capability of applying or using knowledge, skill or abilities, behaviours , personal characteristic to successfully preform critical work, task, specific functions, or operate in a given role or position.(Chouhan, 2014)

Amruta Pujari identified competency essential in Construction sector in India which highlighted the importance of functional and generic 
competencies. The general competencies focused more on communication and the functional competences were divided into behavioural and project management related competencies. This was based on Lomingers competency framework k. (Amruta Pujari, February 2015)

"Proper usage of project management methodology, tools and techniques can add more value to the success of projects and overall business of manufacturing SMEs". (Sudhakar Dasari, 2015).

Sabrina Loufrani-Fedida and StéphanieMissonier, in their study for Project Based Organizations(PBO), recommended that "both practitioners and current academic researchers stop looking for the perfect, "ideal" project manager who would possess all of the necessary critical competencies for projects" (Sabrina Loufrani-Fedida, 2015). The study suggested that the competencies should be considered on both the levels viz. individual competencies and organizational integrative competencies.

Gruden and Stare, from their study identified assertiveness, , relaxation and consulting as the important competences for project realization and leadership was ranked the most important competency amoungst behavioural competency, followed by results orientation, engagement and motivation, reliability, and efficiency (Gruden, 2018)

The above research papers can be summarised in the following table:

\begin{tabular}{|r|l|r|l|}
\hline Sr.No & \multicolumn{1}{|c|}{ Author } & Year & \multicolumn{1}{|c|}{ Contribution } \\
\hline 1 & David McClelland & 1973 & $\begin{array}{l}\text { For the first time offered competencies as critical differentiator of } \\
\text { performance. }\end{array}$ \\
\hline 3 & Richard Boyatzis & 1982 & $\begin{array}{l}\text { Maximum performance is believed to occur when the person's } \\
\text { capability or talent is consistent with the needs of the job demands } \\
\text { and the organizational environment }\end{array}$ \\
\hline 4 & Lee & 1992 & $\begin{array}{l}\text { Interpersonal skills as important for Information Systems (IS) } \\
\text { managers. }\end{array}$ \\
\hline 6 & 1995 & $\begin{array}{l}\text { Business functional knowledge and interpersonal skills were } \\
\text { considered more important than technical skills. }\end{array}$ \\
\hline 7 & Grawford & 1997 & $\begin{array}{l}\text { defined “competency according to three dimensions, which are } \\
\text { project management knowledge, project management performance } \\
\text { and personal competencies }\end{array}$ \\
\hline Gupta and Wachter & 1998 & $\begin{array}{l}\text { Defined competency as ccompetency as performance standard, } \\
\text { which is expected to achieve". This competency is also known as } \\
\text { functional competency (Martin and Staines, 1994) or task-specific } \\
\text { competency (Bergenhengouwen, 1996) or job-focused (Holmes } \\
\text { and Joyee, 1993). Elkin (1990) addressed this competency as } \\
\text { "micro competency". }\end{array}$ \\
\hline $\begin{array}{l}\text { Soft skills to be important like team work, communication and } \\
\text { creativity. }\end{array}$ \\
\hline $\begin{array}{l}\text { A competent project manager is a factor that affects project } \\
\text { success.Divided competency into people related competency, job } \\
\text { related competency \& contextual competency.Soft skills like } \\
\text { communication at multiple levels, tacit knowledge of knowing } \\
\text { when to exercise leadership which leads to project success. }\end{array}$ \\
\hline
\end{tabular}




\begin{tabular}{|c|c|c|c|}
\hline 9 & $\begin{array}{l}\text { MichealBirkhead, } \\
\text { Margaret Sutherland, } \\
\text { and TuxdorMaxwell }\end{array}$ & 2000 & $\begin{array}{l}\text { The order of importance of competency was found be planning } \\
\text { and controlling, personal influence which includes honesty and } \\
\text { integrity, goal focus, problem solving, team leadership, project } \\
\text { team development and project context. Team building emerged as } \\
\text { important competency for IT Project Managers. }\end{array}$ \\
\hline 10 & Lampel & 2001 & $\begin{array}{l}\text { Competencies divided into entrepreneurial, technical and relational. } \\
\text { Technical Competencies:- scope, communication and risk } \\
\text { management.Behavioural / Personal Competencies :- result } \\
\text { orientation, initiative, problem solving and team work. }\end{array}$ \\
\hline 11 & Narendra Agrawal & 2003 & $\begin{array}{l}\text { Due to shortage of Project Managers, many organizations promote } \\
\text { employees at their early career stage, when they are still not } \\
\text { equipped with managerial skills and gaining technical experience. } \\
\text { The paper pointed out the reluctance of employees to make } \\
\text { transition from technical to managerial positions. }\end{array}$ \\
\hline 12 & Gholston & 2004 & $\begin{array}{l}\text { Recommended that project management study courses should be } \\
\text { aligned with the PMBoK Knowledge areas and competencies } \\
\text { specified in the same. }\end{array}$ \\
\hline 13 & Winterton & 2005 & $\begin{array}{l}\text { Explained difference in US and UK approach in competency } \\
\text { framework.USA approach predominantly was behaviour oriented } \\
\text { to which the functional and cognitive component was added while } \\
\text { the UK approach included behaviour competencies to occupational } \\
\text { functional competencies. }\end{array}$ \\
\hline 14 & Chen et.al & 2005 & $\begin{array}{l}\text { Communication skills, both written and verbal as a competency } \\
\text { was observed as important competency }\end{array}$ \\
\hline 15 & Muller & 2005 & $\begin{array}{l}\text { Opined a different that observation that project managers } \\
\text { leadership style and competency have no impact on project success } \\
\text { and cannot be considered as critical success factor due to the novel, } \\
\text { unique and transient nature of projects. }\end{array}$ \\
\hline 16 & 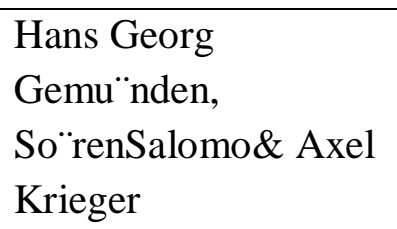 & 2005 & $\begin{array}{l}\text { In case of innovative projects, integration of people from business } \\
\text { functions in cross-functional teams do not lead to significantly } \\
\text { higher project success but instead co-location of people does. }\end{array}$ \\
\hline 17 & Abdullah Mahmood & 2006 & $\begin{array}{l}\text { Competence variables were identified and grouped in to } 4 \\
\text { competences. i.e. cognitive competence, ethical competence, } \\
\text { personal or behavioural competence and functional competence in } \\
\text { the order of importance. }\end{array}$ \\
\hline 18 & Dulewicz & 2006 & $\begin{array}{l}\text { Amoungst cognitive, ethical, behavioural and functional } \\
\text { competence cognitive competence was found to be more important } \\
\text { than others }\end{array}$ \\
\hline 19 & Helgadottir & 2007 & $\begin{array}{l}\text { Identified three dimensions of thinking competencies for Project } \\
\text { Manager which include creative thinking, logical thinking and } \\
\text { ethical thinking. Ethical behaviour of project manager influences } \\
\text { team members. }\end{array}$ \\
\hline 20 & $\begin{array}{l}\text { Linda Henderson; } \\
\text { 2008, Krahn \& }\end{array}$ & & $\begin{array}{l}\text { Listening skills and verbal communication was rated as one of the } \\
\text { top } 10 \text { competencies for project managers. }\end{array}$ \\
\hline
\end{tabular}




\begin{tabular}{|c|c|c|c|}
\hline & Hartment; 2006) & & \\
\hline 21 & Mary .C. Jones & 2008 & $\begin{array}{l}\text { Stressed on the importance of team building, leadership, control } \\
\text { and coordination along with interventions to overcome the } \\
\text { obstacles. }\end{array}$ \\
\hline 22 & $\begin{array}{l}\text { Divine } \\
\text { KwakuAhadzie, } \\
\text { David Gavin Proverbs } \\
\text { \& Paul Olomolaiye }\end{array}$ & 2008 & $\begin{array}{l}\text { Task behaviours are found to be more contributing than contextual } \\
\text { behaviours. }\end{array}$ \\
\hline 23 & Dulewicz & 2008 & $\begin{array}{l}\text { Today's Project manager managers need to be good leaders. He } \\
\text { also re-established the finding that conceptual skills are more } \\
\text { important at senior level and technical skills are more important at } \\
\text { junior level. }\end{array}$ \\
\hline 24 & $\begin{array}{l}\text { Linda Hendersson, } \\
\text { Krahn \& Hartment }\end{array}$ & 2008 & $\begin{array}{l}\text { Listening skills and communication were rated as one of the top ten } \\
\text { competencies essential for Project Manager }\end{array}$ \\
\hline 25 & Richard.E.Boyatzis & 2008 & $\begin{array}{l}\text { Because the competencies are derived from performance } \\
\text { inductively, they reflected effective job performance. Since they } \\
\text { were identified and articulated in terms of the actions and intent, } \\
\text { they are a behavioural approach to a person's talent. }\end{array}$ \\
\hline 26 & Richard Boyatzis & 2008 & $\begin{array}{l}\text { Introduced the three thresh hold clusters of competencies for } \\
\text { performance which are experience, knowledge and reasoning } \\
\text { ability while outstanding competencies include cognitive, } \\
\text { emotional and social intelligence. }\end{array}$ \\
\hline 27 & $\begin{array}{l}\text { Matthew E. } \\
\text { Swinarski, Diane H. } \\
\text { Parente,KathleenNoce }\end{array}$ & 2009 & $\begin{array}{l}\text { Interpersonal and business skills were regarded more important } \\
\text { than technical skills }\end{array}$ \\
\hline 28 & Gregory \& Francis & 2009 & $\begin{array}{l}\text { Leadership competencies for Project Manager in USA Important } \\
\text { were decisiveness, ownership and motivation. }\end{array}$ \\
\hline 29 & $\begin{array}{l}\text { Ali Shirazi\& Saeed } \\
\text { Mortazavi }\end{array}$ & 2009 & $\begin{array}{l}\text { Effective manager is the one who is responsive, proactive, good } \\
\text { communicator, team builder, motivator and decisive }\end{array}$ \\
\hline 30 & $\begin{array}{l}\text { Gregory J. Skulmoski, } \\
\& \quad \text { Francis T. } \\
\text { Hartmanh }\end{array}$ & 2009 & $\begin{array}{l}\text { Studied leadership competencies essential for IT project during } \\
\text { various phases of project to be successful. Objectivity is essential } \\
\text { during Initiation phase, while ownership, decisiveness and } \\
\text { motivations are important during planning and implementation } \\
\text { phase and credit giving ability is found useful during closeout. }\end{array}$ \\
\hline 31 & $\begin{array}{l}\text { Gregory J. Skulmoski, } \\
\text { Francis T. Hartman }\end{array}$ & 2010 & $\begin{array}{l}\text { Communication, listening skills, writing skills, leadership, Ethical } \\
\text { conduct, Quality, Result orientation, Planning and implementation, } \\
\text { Team management, Creativity, eye for detail, self-evaluation } \\
\text { emerged as critical competencies. }\end{array}$ \\
\hline 32 & $\begin{array}{l}\text { Ralf Muller \& } \\
\text { Rodney Turner }\end{array}$ & 2010 & $\begin{array}{l}\text { Influence, motivation, conscientiousness which are the sub } \\
\text { dimensions of EQ were found to be present in all the successful } \\
\text { project managers of all types of projects. Leadership ability of } \\
\text { project managers like influencing and motivating the team are } \\
\text { important for project success. }\end{array}$ \\
\hline
\end{tabular}




\begin{tabular}{|c|c|c|c|}
\hline 33 & Clarke & 2010 & $\begin{array}{l}\text { Emotional Intelligence -EI ability and empathy related to team } \\
\text { work lead to project success. }\end{array}$ \\
\hline 34 & $\begin{array}{l}\text { Manhui Huang and } \\
\text { Chi-Sum Wong }\end{array}$ & 2010 & $\begin{array}{l}\text { The various IT competence include IT application knowledge, } \\
\text { initiative, adaptability, cooperation, communication skill, } \\
\text { innovation and attitude. The study in China concluded that } \\
\text { knowledge can be improved by training and stresses on the fact that } \\
\text { in-depth study of competence is essential. }\end{array}$ \\
\hline 35 & Jo Ann Starkweather & 2011 & $\begin{array}{l}\text { PMP certified does not lead to higher success rate of projects. Soft } \\
\text { skills such as the ability to communicate at multiple levels, and the } \\
\text { tacit knowledge of knowing when to exercise leadership and how } \\
\text { to do this effectively are critical to eventual project success. }\end{array}$ \\
\hline 36 & $\begin{array}{l}\text { Li-RenYanga, Chung- } \\
\text { FahHuangb, Kun- } \\
\text { Shan Wua }\end{array}$ & 2011 & $\begin{array}{l}\text { Transactional and Transformational leadership of project managers } \\
\text { improves project performance. }\end{array}$ \\
\hline 37 & Stevenson & 2011 & $\begin{array}{l}\text { PMP certification was one of the least valued competency. } \\
\text { Leadership, communication, verbal \& written skills ability to deal } \\
\text { with ambiguity, cultural fit, technical expertise team size, ability to } \\
\text { escalate were found important. }\end{array}$ \\
\hline 38 & $\begin{array}{l}\text { Jan Bartoška, Martin } \\
\text { Flég11 \& Martina } \\
\text { Jarkovská }\end{array}$ & 2012 & $\begin{array}{l}\text { Technical competency was considered more important than } \\
\text { behaviour and contextual competencies. The article defines IPMA } \\
\text { standard competence minimum. }\end{array}$ \\
\hline 39 & $\begin{array}{l}\text { PanagiotisTrivellas, } \\
\text { Christos Drimoussis }\end{array}$ & 2013 & $\begin{array}{l}\text { The crucial behavioural, managerial and emotional competency } \\
\text { areas as well as the leadership styles contributing most to project } \\
\text { success have been identified.Amoungst managerial competencies; } \\
\text { ethical values, openness and reliability emerged as the most } \\
\text { dominant competencies. Successful Project managers exhibited } \\
\text { high level of self-awareness amongst emotional competency. . }\end{array}$ \\
\hline 40 & Pandya & 2014 & $\begin{array}{l}\text { Emphasized the role of project manager as a bridge between } \\
\text { stakeholders, ground worker, staff, management, and project } \\
\text { sponsors. Focused on behavioural competencies ;technical } \\
\text { competencies ones being the prerequisite }\end{array}$ \\
\hline 41 & $\begin{array}{l}\text { Sabrina Loufrani- } \\
\text { Fedida and } \\
\text { StéphanieMissonier }\end{array}$ & 2015 & $\begin{array}{l}\text { In case of Project Based Organizations(PBO), organizations should } \\
\text { not focus only on the individual Project Mangers competencies but } \\
\text { consider organizational integrative competencies as well. }\end{array}$ \\
\hline 42 & Gruden and Stare & 2018 & $\begin{array}{l}\text { Assertiveness emerged as an important competence and leadership } \\
\text { was considered important competency by Project Managers . }\end{array}$ \\
\hline
\end{tabular}

\section{CONCLUSION}

Competence was first discussed by David McClellandfollowed by various behavioural researchers.Majority of the papers agreed to the concept of competency as the capability of applying the knowledge, skill and attitude to the successful performance at work place.Few papers provided the distinction between competence and competencies and the different types of competencies.

The different types of competencies essential for project managers majorly included the technical competencies, behavioural competencies and the business functional competencies to name a few. Many papers identify behavioural competency as people related competency or soft skills or 
interpersonal skills while the term technical skills or technical competency remains constant. The distinction is made as technical competency and soft skills; or people skills, people related competencies and technical skills or competency However, upon analysis of the above papers, it can been seen that for the role of Project Manager, the behaviour competencies are perceived to be more important than the technical competencies. More so, the competency of communication, team building,leadership and listening skills take a lead in the behavioural competency. Communication skills in terms of both verbal and oral communication along with listening skills gained a upper hand in competences. Different view was observed only in one paper where project manager leadership and competency did not have any impact on project success due to novel, unique and transient nature of project.

\section{LIMITATION AND FUTURE SCOPE OF} RESEARCH: This research is limited to technical and behaviour competencies. An indepth study of these competencies along with other contextual competencies need to be carried out.

\section{REFERENCES}

[1] Amruta Pujari, D. S. (February 2015). NEED FOR COMPETENCY MAPPING OF PROJECT MANAGERS IN INDIAN CONSTRUCTION SECTOR. International Journal of Advanced Technology in Engineering and Science, 492-500.

[2] Almusaddar, Ayman AS, Sara Ravan Ramzan, and Valliappan Raju. "The Influence of Knowledge, Satisfaction, and Motivation on Employee Performance Through Competence." International Journal of Business and General Management (IJBGM) 7.5 (2018): 21-40.

[3] Ampu Harikrishnan, Ms, and Sunita Kumari. "A Study on the Effect of
Organizational Culture on Performance Management and Competency Development in a Private University in Himachal Pradesh." International Journal of Research and Analytical: 76.

[4] Boyatzis, R. (1982). The competent Manager .

[5] Boyatzis, R. E. (2008). Competencies in the 21st century. "Journal of Management Development, 5-12.

[6] C.Jones, M. (2008, OCTOBER ). Large Scale Project TeaM bUILDING : Beyond The Basics. COMMUNICATIONS OF THE ACM, 51(10), 113-116.

[7] Chouhan, S. S. (2014, January ). Understanding Competencies and Competency Modeling - A Literature Survey. IOSR Journal of Business and Management (IOSR-JBM), 16(1), 14-22.

[8] CII, K. (2012). Project Management Need of Hour . KPMG,PMI \& CII.

[9] Clarke, N. (2010). Emotional Intelligence and Its Relationship to Transformational Leadership and Key Project ManagerCompetences. Project Management Journal, Vol. 41, No. 2,, 520.

[10] Crawford, L. (2000). Project management competence for the new millenium. 15th World Congress on Project Management . London .

[11] Dalton, M. (1997). Are Competency Models a Waste? Training and Development , 46-49.

[12] Dean A. Shepherd, H. P. (2014). How Does Project Termination Impact Project Team Members? Rapid Termination, 'Creeping Death', andLearning from Failure. Journal of Management Studies 51:4 June 2014, 514-544.

[13] Divine Kwaku Ahadzie, D. G. (2008). Towards developing competency-based measures for construction project managers: Should contextual behaviours be distinguished from task behaviours? 
International Journal of Project Management 26 (2008) 631-645, 631-645.

[14] Dr. Abdullah Mahmood, A. M. (2006). WHAT COMPETENCIES DO PROJECT MANAGERS NEED? ICCI 2006.

[15] Dubé, L. (2014). Exploring How IT Professionals ExperienceRole Transitions at the End of Successful Projects. Journal of Management Information Systems / Summer 2014, Vol. 31, No. 1, 17-45.

[16] Dulewicz, L. G. (December 2008). Do Project Managers' Leadership Competencies Contribute to Project Success? Project Management Journal, Vol. 39, No. 4, 58-67.

[17] Dulewicz, M. Y. (2008). Similarities and Differences between Leadership and Management:High-Performance

Competencies in theBritish Royal Navy. British Journal of Management, Vol. 19, 17-32.

[18] Elashkar, Magdy Ali. "the Use of Simulation Techniques in the Development of Non-Technical Skills for Marine Officers." International Journal of General Engineering and Technology (IJGET) 5.5 (2016): 19-26.

[19] FICCI. (2011). A Framework for Effective Adoption of Project Management in India. FICCI \& PMI.

[20] Ghasem Omidvar, F. J. (2011). A Proposed Framework for Project Managers' Competencies and Role of EPortfolio to Meet These Competencies. International Journal of e-Educatio, 1(4), 311-321.

[21] Ghasem Omidvar, F. J. (2011). IMPORTANCE DEGREE OF TECHNICAL COMPETENCIES IPEDR vol.13 (2011) (C) (2011) IACSIT Press, Singapore. 2011 2nd International Conference on Education and Management Technology, (pp. 150-153). Singapore.

[22] Gholston, T. A. (September 2004). Project Manager Skill Development:A Survey of
Programs and Practitioners. Engineering Management Journal Vol. 16 No. 3 , 1016.

[23] Gregory J. Skulmoski, F. T. (2010, March 2010). Information Systems Project Manager Soft Competencies: A ProjectPhase Investigation. Project Management Journal, Vol. 41 ( No. 1), 61-80.

[24] Gruden, S. A. (2018). The Influence of Behavioral Competencies on Project Performance. Project Management Journal, 98-109.

[25] Guido Capaldo, L. I. (2006). A situationalist perspective to competency management. Human Resource Management. 429-448.

[26] Hans Georg Gemu“nden, S. S. (2005). The influence of project autonomy on project success. International Journal of Project Management 23 (2005) 366-373 36, 366373.

[27] Hartman, G. J. (2009). The temporal nature of Project Leadership : an Empirical Investigation. Proceedings of the European Conference on Management, Leadership \& Governance2009, p242, (pp. 242-249).

[28] Henderson, L. S. (2008). "The Impact of Project Managers' Communication Competencies: Validation and Extension of a Research Model for Virtuality, Satisfaction, and Productivity. "Project Management Journal, Vol. 39, No. 2, 4859, 48-59.

[29] IPMA Competence Baseline version3.0. (2006). Retrieved from www.aipm.com: https://www.aipm.com.au/documents/aipm -key-

documents/ipma_pm_assessment_compete nce_baseline.aspx

[30] Isabel Ortiz-Marcos, J. R. (2013). Competency Training for Managing International Cooperation Engineering Projects. Project Management Journal, Vol. 44, No. 2, 88-97, 88-97. 
[31] Jan Bartoška, M. F. (October 2012). IPMA Standard Competence Scope in Project Management Education. International Education Studies; Vol. 5, No. 6; 2012, 167-176.

[32] Jo Ann Starkweather, D. H. (2011, February). PMP® Certification as a Core Competency: Necessary But Not Sufficient. Project Management Journal, Vol. 42, No. 1, 31-41.

[33] Lampel, J. (2001). The core competencies of effective project execution:the challenge of diversity. International Journal of Project Management 19 (2001) 471-483, 471-483.

[34] Li-Ren Yanga, C.-F. H.-S. (2011). The association among project manager's leadership style, teamwork and project success. International Journal of Project Management 29 (2011) 258-267 261, 258267.

[35] Matthew E. Swinarski, D. H. (2009, January ). Are all IT professionals created equally? Journal of Behavioral Studies in Education, 1-11.

[36] McClelland, D. (1973 January). Testing for Competence Rather Than for Intelligence. American Psychologist, 1-14.

[37] Micheal Birkhead, M. S. (2000). Core competencies required of Project Managers . South African Journal of Business Management , 99-105.

[38] Micheal Birkhead, M. S. (2001). Core Competencies required of Project Managers . South African Journal of Business Management .

[39] Mortazavi, A. S. (January 2009). Effective Management Performance A CompetencyBased Perspective. "International Review of Business Research Papers, 1-10.

[40] Muller, J. R. (2005). THE PROJECT MANAGER'S LEADERSHIP STYLE AS A SUCCESS FACTOR ON PROJECTS: A LITERATURE REVIEW. Project Management Journal, 49-61.
[41] Narendra M. Agrawal, M. T. (2003). Human resource issues, challenges and strategies in the Indian software industry. INTERNATIONAL JOURNAL OF HUMAN RESOURCES DEVELOPMENT AND MANAGEMENT - JANUARY.

[42] Panagiotis Trivellas, C. D. ( 2013 ). Investigating Leadership Styles, Behavioural and Managerial Competency Profiles of Successful Project Managers in Greece. Panagiotis Trivellas and Procedia Social and Behavioral Sciences 73, $692-$ 700.

[43] Perrenoud.P. (1997). Building school skills:Practices and educational challenegs

[44] PMI. (2012). Study on Perspectives of Indian Organizations on Project Management Skills. PMI.

[45] Ralf Muller, R. (2010). Leadership competency profiles of successful project managers. International Journal of Project Management 28 (2010) 437-448, 437-448.

[46] Richard.E.Boyatzis. (2008). Competencies for the 21st century. Journal of Management Development, 27(1), 5-12.

[47] Sabrina Loufrani-Fedida, S. M. (2015). The project manager cannot be a hero anymore! Understanding critical competencies in project-based organizations from a multilevel approach. International Journal of Projetc Management .

[48] Sanghi, S. (2002, January-March ). Ethical Issues at Work: A Comparative Study between UK and Indian Managers. Vikalpa, 27, 21-33.

[49] Sanghi, S. (2007). The handbook of competency mapping. New Delhi: Sage Publications.

[50] Shi-Rui Song, A. G. (Aug2007). THE IMPORTANCE OF CHINESE PROJECT MANAGERS'WORK VALUES. Cross Cultural Management. , 894-902. 
[51] SHARMA, GARIMA. "A CRITICAL STUDY OF THE BIOLOGY CURRICULUM AT SENIOR SECONDARY STAGE WITH RESPECT TO LIFE SKILLS EDUCATION AND THE HIV/AIDS EDUCATION." IASET: International Journal of Library \& Educational Science (IASET: IJLES) 2.3, Apr - May 2016; 1-10

[52] Stevenson, J. A. (2011). PMP® Certification as a Core Competency: Necessary But Not Sufficient. Project Management Journal, Vol. 42, No. 1, 3141, 31-41.

[53] Sudhakar Dasari, N. J. (2015). Analysis of Project Success Issues:The Case of a Manufacturing SME. The IUP Journal of Operations Management, Vol. XIV, No. 1, , 32-39.

[54] UPRETI, RASHMI, and RITU SINGH. "A study of differences in adaptive behavioral skills of mentally challenged children with gender." International Journal of Humanities and Social Sciences 5 (2016): 87-94.

[55] WINTERTON, F. O. ( March 2005). What Is Competence? Human Resource Development International, Vol. 8, No. 1, 27 - 46, 27-46.

[56] Wong, M. H.-S. ( October 2010). First-line and Middle Manager Competence,Usage Intention and IT Application Maturity. International Journal of Innovation, Management and Technology, Vol. 1, No. 4, 349-353. 